\title{
The CD40-CD40L Pathway Contributes to the Proinflammatory Function of Intestinal Epithelial Cells in Inflammatory Bowel Disease
}

\author{
Frauke Borcherding, ${ }^{* \dagger}$ Martin Nitschke, ${ }^{*}$ \\ Gheorghe Hundorfean, ${ }^{*}$ Jan Rupp, ${ }^{*}$ \\ Dorthe von Smolinski, ${ }^{\dagger}$ Katja Bieber, ${ }^{\dagger}$ \\ Cees van Kooten, ${ }^{\S}$ Hendrik Lehnert, ${ }^{*}$ \\ Klaus Fellermann, ${ }^{*}$ and Jürgen Büning ${ }^{\star \dagger}$ \\ From the Department of Internal Medicine I, ${ }^{*}$ and the Institute of \\ Microbiology and Hygiene, University Hospital of Schleswig- \\ Holstein, Lübeck, Germany; the Institute of Anatomy, ${ }^{\dagger}$ University of \\ Lübeck, Lübeck, Germany; and the Department of Nephrology, ${ }^{\$}$ \\ Leiden University Medical Center, Leiden, The Netherlands
}

In inflammatory bowel diseases (IBD), intestinal epithelial cells (IECs) are involved in the outbalanced immune responses toward luminal antigens. However, the signals responsible for this proinflammatory capacity of IECs in IBD remain unclear. The CD40/CD40L interaction activates various pathways in immune and nonimmune cells related to inflammation and was shown to be critical for the development of IBD. Here we demonstrate CD40 expression within IECs during active IBD. Endoscopically obtained biopsies taken from Crohn's disease $(n=112)$ and ulcerative colitis patients $(n=67)$ consistently showed immunofluorescence staining for CD40 in IECs of inflamed ileal or colonic mucosa. In noninvolved mucosa during active disease, tissue obtained during Crohn's disease or ulcerative colitis in remission and biopsies from healthy controls $(n=38)$ IECs almost entirely lacked CD40 staining. Flow cytometry and RT-PCR analysis using different intestinal epithelial cell lines (HT29, SW480, and T84) showed IFN- $\gamma$ to effectively induce CD40 in IECs. Cells were virtually unresponsive to LPS or whole $E$. coli regarding CD40 expression. In addition, a moderate induction of CD40 was found in response to TNF- $\alpha$, which exerted synergistical effects with IFN- $\gamma$. CD40 ligation by CD40L-transfected murine fibroblasts or soluble CD40L increased the secretion of IL-8 in IFN- $\gamma$ pretreated HT29 cells. Our findings provide evidence for the epithelial expression and modulation of CD40 in IBD-affected mucosa and indicate its involvement in the proinflammatory function of IECs. (Am J Pathol 2010, 176:1816-1827; DOI: 10.2353/ajpath.2010.090461)

Crohn's disease (CD) and ulcerative colitis (UC) are common inflammatory disorders of the intestine. Inflammation in these entities of inflammatory bowel disease (IBD) results from a complex interaction of genetic, environmental, microbial, and immune factors primarily driven by defects of the mucosal barrier., ${ }^{1,2}$ The secondary loss of tolerance toward microbiota or dietary antigens of the gut lumen leads to an inappropriate and continuous activation of the mucosal immune system.

Intestinal epithelial cells (IECs) represent the critical interface between the environment and host. IECs are known to be involved in the regulation of mucosal immune responses to luminal antigens. ${ }^{3,4}$ They function as antigen presenting cells (APCs) to different subsets of $T$ cells $^{3,5-7}$ and moreover play a role in the innate immune response through secretion of a panel of cytokines and chemokines. ${ }^{8-11}$ In this regard IECs substantially contribute to the inflammatory processes in IBD by stimulating effector $T$ cells and the release of interleukin (IL)-1, IL-6, IL-8, or tumor necrosis factor (TNF)- $\alpha$. However, the signals that drive IECs to function as a proinflammatory mediator during IBD remain incompletely understood.

CD40 is a 45 - to $50-\mathrm{kDa}$ cell-surface glycoprotein that belongs to the TNF-receptor family and was initially described on B cells. ${ }^{12}$ Subsequently, CD40 was identified on various cell types such as professional APCs, endothelial cells, epithelial cells of different organs, and fibroblasts. ${ }^{13,14}$ Its ligand, CD40L, is a 39-kDa surface glycoprotein and a member of the TNF gene superfamily. CD40L is mainly

Supported by grants of the Medical Faculty, University of Lübeck (SPP Autoimmunity B6 to J.B. and Junior Cluster "Entzündung des Epithels ein Balanceakt to J.B.)

F.B. and M.N. contributed equally to this study

Accepted for publication December 15, 2009.

Address reprint requests to Jürgen Büning, M.D., Department of Internal Medicine I, University Hospital of Schleswig-Holstein, Ratzeburger Allee 160, D-23538 Lübeck, Germany. E-mail: juergen.buening@uk-sh.de. 
expressed on activated $\mathrm{CD} 4^{+}$T-helper cells and platelets but could also be found on cytotoxic CD8 ${ }^{+} T$ cells. ${ }^{13,15,16}$ Produced as a transmembrane protein CD4OL may be present as cell surface heteromultimeric complex composed of membrane bound and soluble forms (sCD4OL). The interaction between CD40 and CD40L exerts pleiotropic functions. ${ }^{13-17}$ Among these the engagement of CD40 on APCs or epithelial cells is accompanied by the upregulation of Major Histocompatability Complex $(\mathrm{MHC})$ and costimulatory molecules such as CD80 or CD86. The CD40mediated stimulation further results in the secretion of a row of cytokines/chemokines such as IL-1, IL-6, IL-8, IL-12, and TNF- $\alpha$.

Studies in animal models demonstrate a crucial role of the CD40-CD40L system in autoimmune diseases such as collagen-induced arthritis, experimental allergic encephalomyelitis, and lupus nephritis. ${ }^{18-20}$ Remarkably, Stuber et al showed that the CD40-CD4OL interaction is also an important element in the pathogenesis of colitis. ${ }^{21}$ Blocking the CD40-CD40L system using anti-CD4OL antibodies, authors found a prevention of the TNBS-induced colitis. In addition, CD40L transgenic mice with the highest transgene copy numbers were reported to acquire a lethal bowel inflammation resembling IBD. ${ }^{22}$ The particular relevance of this system in $C D$ or UC is further emphasized by evidence obtained from IBD patients. CD40, CD40L, and SCD40L were observed to be strongly up-regulated in course of active $C D$ and UC, particularly within the inflamed mucosa. ${ }^{23-25}$

These data suggest that the CD40-CD40L system might be essentially involved in the proinflammatory action of IECs during IBD. Of note, the expression and potential function of CD40 in IECs, especially in the context of IBD, still remain to be elucidated. In this study we provide evidence for the epithelial expression of CD40 in IBD, its modulation, and functional implication in the processes of mucosal inflammation.

\section{Materials and Methods}

\section{Patients and Ethics}

For immunofluorescence analysis mucosal biopsies were obtained from subjects undergoing ileocolonoscopy. Patients were recruited on the basis of $C D$ and $U C$ with active disease or remission (CD: active $n=77$, remission $n=35$; UC: active $n=40$, remission $n=27$ ). Biopsies were taken in the terminal ileum in $\mathrm{CD}$ patients and controls. Colonic tissue was obtained from patients with $C D, U C$, and controls. In patients with colonic inflammation biopsies were simultaneously taken from affected mucosa and adjacent noninflamed areas. CD- or UC-specific inflammation and noninflamed mucosa during remission or in nonaffected areas was confirmed by histopathology. The diagnosis of $\mathrm{CD}$ or UC had been established by clinical, radiological, endoscopical, and histopathological criteria. An infectious cause of acute inflammation was excluded. CD and UC treatment consisted of mesalamine, budesonide, prednisolone, azathioprine, 6-mecaptopurine, and methotrexate. Patients undergoing ileocolonoscopy for carcinoma screening, gastrointestinal bleeding, constipation, or ob-
Table 1. Patient Characteristics

\begin{tabular}{|c|c|c|c|c|c|}
\hline & $N=$ & Female & Male & $\begin{array}{l}\text { Mean } \\
\text { Age }\end{array}$ & Range \\
\hline \multicolumn{5}{|l|}{ CD } & (17 to 87 ) \\
\hline \multicolumn{6}{|l|}{ Ileum } \\
\hline Active disease & 29 & 15 & 14 & 42.6 & (26 to 66 ) \\
\hline Remission & 15 & 10 & 5 & 44.3 & (19 to 60$)$ \\
\hline \multicolumn{6}{|l|}{ Colon } \\
\hline Active disease & 48 & 33 & 15 & 39.2 & (19 to 82 ) \\
\hline Remission & 20 & 14 & 6 & 47.2 & (19 to 70$)$ \\
\hline \multirow{2}{*}{\multicolumn{6}{|c|}{ UC }} \\
\hline Colon & & & & & \\
\hline Active disease & 40 & 23 & 17 & 41.5 & (17 to 70$)$ \\
\hline Remission & 27 & 15 & 12 & 49.7 & (24 to 77 ) \\
\hline \multicolumn{6}{|l|}{ Healthy control } \\
\hline Ileum & 17 & 11 & 6 & 51.8 & (20 to 85 ) \\
\hline Colon & 21 & 14 & 7 & 56.8 & (19 to 87 ) \\
\hline
\end{tabular}

scure abdominal pain served as controls $(n=38)$. In these patients tissue was obtained from macroscopically healthy tissue and biopsies showed a regular histology throughout. Control patients did not receive any immunomodulatory drugs. Sex and age of patients are given in Table 1.

Written informed consent was obtained from all patients. The experiments received local ethical approval (Medical Faculty, University of Lübeck: 02-073, 03-043).

\section{Immunofluorescence Microscopy}

Endoscopically obtained biopsies were snap frozen in liquid-nitrogen. Cryosections $(6 \mu \mathrm{m})$ were air-dried, fixed in acetone-methanol (1:1), and incubated with a mouse monoclonal antibody against human CD40 (clone mAB89; Immunotech, Beckman Coulter, Krefeld, Germany) or IL-8 (clone NAPII; Bender MedSystems, Vienna, Austria), and the appropriate anti-mouse IgG Alexa-488 conjugate (Molecular Probes, Invitrogen, Karlsruhe, Germany) for 60 minutes each. Bis-benzimide (Sigma-Aldrich, Taufkirchen, Germany) was used to stain nuclei. Immunofluorescence analysis was done by confocal laser-scanning microscopy using a Zeiss (Jena, Germany) LSM 510 Meta.

\section{Cells}

The intestinal epithelial cell lines HT29, SW480, and T84 were obtained from the American Type Culture Collection. Mouse fibroblastic $L$ cells and $L$ cells stably transfected with the human CD40L (L-CD40L cells) were a kind gift of Dr. Cees van Kooten. ${ }^{26}$ Cells were kept under humidified conditions at $37^{\circ} \mathrm{C}$ and $5 \% \mathrm{CO}_{2}$. DMEM high glucose was used for HT29 cells, DMEM/Ham F-12 for SW480, and T84 cells and RPMI 1640 for L/L-CD40L cells. Media were supplemented with $10 \%$ heat-inactivated FCS, $2 \mathrm{mmol} / \mathrm{L}$ L-glutamine, $100 \mathrm{U} / \mathrm{ml}$ penicillin, and $100 \mu \mathrm{g} / \mathrm{ml}$ streptomycin.

\section{Flow Cytometry}

HT29, SW480, and T84 cells, grown to confluence, were stimulated with IFN- $\gamma(200 \mathrm{U} / \mathrm{ml}$; R\&D Systems, Wiesba- 
den, Germany), TNF- $\alpha$ ( 1 to $100 \mathrm{ng} / \mathrm{ml}$; R\&D Systems), and LPS (10 to $1000 \mathrm{ng} / \mathrm{ml}$; Sigma-Aldrich) alone or in combination for 72 hours. For FACS analysis $1 \times 10^{5}$ cells were stained for 30 minutes with the monoclonal mouse anti-human CD40 antibody (clone mAB89; Immunotech) or the corresponding isotype control (mouse IgG1; BD Pharmingen, Heidelberg, Germany) on ice. Goat anti-mouse IgG conjugated to PE (Molecular Probes) served as secondary antibody. Flow cytometry was done on a Becton Dickinson FACS Calibur (BD Biosciences, Heidelberg, Germany). Cell Quest Pro software was used for data analysis.

\section{RNA Extraction and Reverse Transcription}

For analysis of the CD40 mRNA expression HT29, SW480, and T84 cells were stimulated with IFN- $\gamma$ and TNF- $\alpha$. HT29 cells were further incubated with supernatant obtained from IFN- $\gamma$-pulsed cells, SCD4OL, LPS, and whole E. coli (see bacterial stimulation). Expression levels of IL-8 mRNA were additionally studied in these cells. For analysis cells were harvested after different periods between 4 and 72 hours. Total RNA was extracted using the RNeasy mini kit (Qiagen, Hilden, Germany and Analytik Jena, Jena, Germany) according to the manufacturer's instructions. For cDNA synthesis $1 \mu \mathrm{g}$ RNA was digested with DNase 1 (Sigma-Aldrich). Reverse transcription was performed using $100 \mathrm{U}$ Superscript II, 0.01 M DTT, 1X reaction buffer (each obtained from Invitrogen), $250 \mathrm{ng}$ of random hexamers (Promega, Mannheim, Germany), and $0.5 \mathrm{mmol} / \mathrm{L}$ dNTP (PeqLAB, Erlangen, Germany) in a total volume of $20 \mu \mathrm{l}$ for 50 minutes at $42^{\circ} \mathrm{C}$.

\section{Real-Time Quantitative PCR}

PCR primers and TaqMan probes for CD40, IL-8, and the housekeeping gene MLN51 (metastatic lymphnode 51) were designed using Primer Express software (Applied Biosystems, Foster City, CA) synthesized by MWG Biotech (Ebersberg, Germany). TaqMan probes were labeled with FAM as reporter and TAMRA as quencher. The following sequences for primers and probes from $5^{\prime}$ to $3^{\prime}$ end were used: CD40 forward, 5'-GCAGTGCGTCCTCTGGGG-3', CD40 reverse, 5'-TTCTGTCCTGGCTGGCACAA-3', CD40 probe 5'-TGCTTGCTGACCGCTGTCCATCCAGA-3'; IL-8 forward, 5'-TGAGAGTGATTGAGAGTGGACCA-3', IL-8 reverse, 5'-TCAGCCCTCTTCAAAAACTTCTCC-3', IL-8 probe 5'-CCCTCTGCACCCAGTTTTCCTTGGGG-3'; MLN51 forward, 5'-CTTCATCTGCGGCGGCGGGTG-3', MLN51 reverse, 5'-ACCTTCAATGCCATCTTCACTCT-3', MLN51 probe 5'-ACTCCGACTCCTCAGCACTCTTGGCG-3'.

Optimized runs were performed on an ABI Prism 7000 sequence detector (Applied Biosystems, Foster City, CA), started with 10 minutes at $95^{\circ} \mathrm{C}$ and followed by 50 cycles of 15 seconds at $95^{\circ} \mathrm{C}$ and 1 minute at $60^{\circ} \mathrm{C}$. PCRs were done using: $2 \mu \mathrm{l}$ of sample DNA, $12.5 \mu \mathrm{l}$ of PCR master mix (Eurogentec, Seraing, Belgium), and $10.5 \mu \mathrm{l}$ DEPC-treated water to give a final volume of $25 \mu$ l. The concentration of each sense and antisense primer for
MLN51 was $500 \mathrm{nmol} / \mathrm{L}, 700 \mathrm{nmol} / \mathrm{L}$ for CD40, and 500 $\mathrm{nmol} / \mathrm{L}$ for IL-8. Optimized concentrations used for TaqMan probes were $250 \mathrm{nmol} / \mathrm{L}$ (MLN51), $200 \mathrm{nmol} / \mathrm{L}$ (CD40), and $100 \mathrm{nmol} / \mathrm{L}$ (IL-8). Samples and no template controls were included in each run as duplexes, and each run was performed twice. Standard curves were generated based on these results applying PCR software (Applied Biosystems) to monitor the kinetics of reaction. Relative gene expression of CD40 and IL-8 was calculated on the base of $\mathrm{Ct}$ values of two independently performed PCR runs (ratio $=2^{-\Delta \Delta C T}$ ). Ratios represent gene expression in relation to expression levels of MLN51.

\section{Bacterial Stimulation}

Whole nonpathogenic E. coli (ATCC 25922) were grown on blood-agar (COS). The bacteria were harvested, washed with PBS, and apically given to confluent HT29 cells in a ratio of 10:1. For these experiments the DMEM high glucose medium was primarily used without any FCS and antibiotics. In case of a HT29 exposure to replicating bacteria for 48 hours, gentamicin $(20 \mu \mathrm{g} / \mathrm{ml}$; Sigma-Aldrich) was added after 4 hours to stop the bacterial proliferation for the remaining 44 hours of incubation. Cell viability was ascertained at different periods with trypan blue (Sigma-Aldrich).

\section{ELISA}

IL-8 secretion by HT29 cells was determined in response to cell-bound CD4OL or SCD40L. HT29 cells, which compared with SW480 and T84 cells display the most disseminated growth behavior, were used to optimize the cell/cell contact with $L$ and L-CD $40 \mathrm{~L}$ cells. $5 \times 10^{5} \mathrm{HT} 29$ cells were seeded in transwell inserts (pore size $0.4 \mu \mathrm{m}$; BD Pharmingen) and treated with $200 \mathrm{U} / \mathrm{ml} \mathrm{IFN-} \gamma$ for 72 hours. $5 \times 10^{5} \mathrm{~L}$-CD40L or nontransfected L cells were added to the stimulated HT29 cells in a subconfluent state. Cells were left in coincubation for 72 hours. For analysis of the SCD4OL stimulation IFN- $\gamma$-activated HT29 cells were grown to confluence. SCD40L was applied as human recombinant SCD40L in a trimeric $16.3 \mathrm{kDa}$ form (Bender MedSystems, Vienna, Austria) and exposed to the basolateral compartment of the transwell system for 72 hours $(0.1$ to $100 \mathrm{ng} / \mathrm{ml})$. Concentrations of IL-8 were assessed in the basolateral chamber by sandwich enzyme-linked immunosorbent assay (ELISA; R\&D Systems) according to the manufacturer's protocol. The measurement was read at $450 \mathrm{~nm}$ wavelength with a Bio-Tek (Bad Friedrichshall, Germany) ELISA reader. Results are expressed as mean \pm SEM of three independent experiments.

\section{Statistical Analysis}

Statistical analysis was done using Student $t$ test and significance assumed $P \leq 0.05$. 

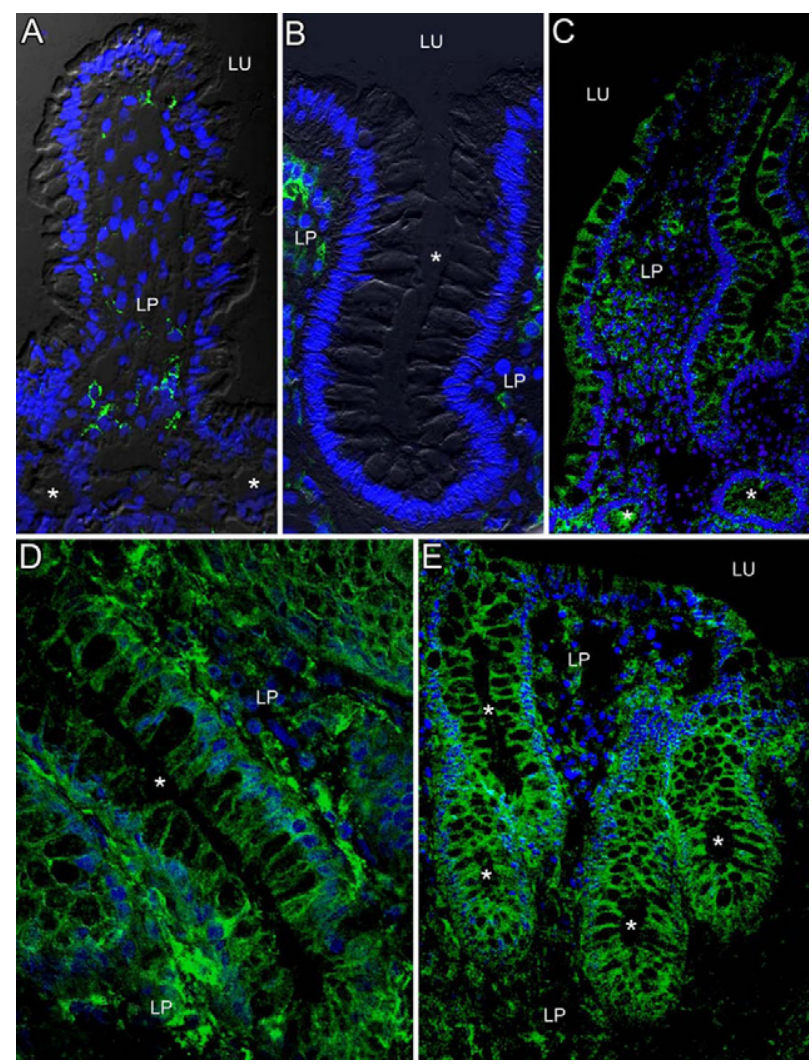

Figure 1. Expression of CD40 in intestinal epithelial cells during active crohn disease (CD) and ulcerative colitis (UC). Immunofluorescence staining for CD40 (green) was performed on cryosections of endoscopically obtained biopsies. In the healthy ileum (A) and colon (B) IECs lacked staining for CD40. In contrast, CD40 was detected on IECs during CD ileitis (C), CD colitis (D), and UC (E). Epithelial staining for CD 40 was found in crypts (asterisks), villi, and the colonic surface epithelium. On the subcellular level CD40 was predominantly localized on basolateral membranes of IECs. Cells of the lamina propria (LP) revealed CD 40 staining independent of the inflammatory state. Lu indicates lumen.

\section{Results}

\section{CD40 Expression in Intestinal Epithelial Cells during Active Inflammatory Bowel Disease}

For the analysis of mucosal CD40 expression in the course of IBD immunofluorescence staining on endoscopically obtained biopsies was used. Stained sections were studied by an investigator unaware of any clinical information and the expression determined based on a comparison with the corresponding isotype control. Expression of CD40 in IECs was assumed in case of a valid staining for CD40 in crypts and the villus/surface epithelium consistently seen throughout 10 to 20 randomly chosen high power fields at a $\times 40$ magnification.

With few exceptions IECs of the healthy ileum lacked expression for CD40 (Figures $1 \mathrm{~A}$ and 2A). IECs of the colon lacked CD40 staining in all control patients examined (Figure 1B and 2A). In both localizations the healthy mucosa consistently revealed $\mathrm{CD} 40^{+}$cells within the lamina propria (Figure 1, A and B). By contrast CD40 expression in IECs was found to be markedly up-regulated in course of active IBD. In the vast majority of patients with $\mathrm{CD}$ ileitis (Figure 1C and 2B), Crohn's colitis
(Figure 1D and 2B) and active UC (Figure 1E and 2C) the inflamed tissue showed staining for CD40 within the epithelium. The epithelial expression for CD40 in affected mucosa was similarly seen in crypts and villi in the ileum and crypts and the surface epithelium in the colon. On the subcellular level CD40 appeared to be expressed in a polarized fashion and confined to the basolateral membranes of IECs (Figure 1, C-E). Infiltrates of $\mathrm{CD}_{4} 0^{+}$cells in the lamina propria strongly increased during mucosal inflammation in both CD and UC (Figure 1, C-E). Of note, in $\mathrm{CD}$ and $\mathrm{UC}$ patients with active colonic disease the induction of CD40 in IECs was restricted to inflamed areas. In almost all patients nonaltered colonic mucosa taken during colitis directly adjacent to the inflamed tissue showed a lack of CD40 in IECs (Figure 2D). In line with this, biopsies obtained during remission from ileal or colonic mucosa formerly affected in the course of CD or UC showed absence of staining for CD40 in IECs (Figure 2, B and C).

\section{IFN- $\gamma$ and TNF- $\alpha$ Induce the Expression of CD40 in Intestinal Epithelial Cells}

Our immunofluorescence results suggested the expression of CD40 in IECs to be related to the inflammatory status of the mucosa in active IBD. Although highly indicative, the immunofluorescence staining on tissue sections does not necessarily prove the expression of the protein by the corresponding cells. Moreover we were interested in unraveling the mediators responsible for the assumed induction of epithelial CD40 in CD and UC. Thus the expression of CD40 was investigated on the protein (Figure 3) and RNA level (Figure 4) in the phenotypically distinct intestinal epithelial cell lines HT29, SW480, and T84. Cells were stimulated with IFN- $\gamma$ and TNF- $\alpha$ alone or in combination. IFN- $\gamma$ and TNF- $\alpha$ had been demonstrated as potent inductors of CD40 in other cell types and are known to be key mediators in the pathogenesis of $\mathrm{CD}$ and $\mathrm{UC} \mathrm{.}^{1,13}$

Analyzed by flow cytometry cell surface-expression of CD40 was not detectable in any of the cell lines without stimulation (Figure 3 ). IFN- $\gamma$ consistently stimulated CD40 in HT29 and T84 cells, however in different efficacies. Whereas a marked induction was observed in HT29 (Figure 3, A and B) and T84 cells (Figure 3, E and F), the CD40 expression was only weakly stimulated by IFN- $\gamma$ in SW480 cells (Figure 3, C and D). Heterogeneous results were obtained for TNF- $\alpha$. HT29 cells did not show any response to TNF- $\alpha$ regarding CD40, even used in high doses up to $100 \mathrm{ng} / \mathrm{ml}$ (Figure 3, A and B). SW480 (Figure 3, C and D) and T84 (Figure 3, E and F) cells showed a concentration-dependent increase of the CD40 expression on TNF- $\alpha$. The most intensive response to TNF- $\alpha$ was seen in T84 cells. Using TNF- $\alpha$ in parallel to IFN- $\gamma$ was done to unravel additive stimuli on the expression of CD40. The combination of proinflammatory agents reflects an approach to the "real situation" in IBD, which is driven by a concert of numerous cytokines and chemokines. The combination of IFN- $\gamma$ and TNF- $\alpha$ was observed to be most effective for the induction of CD40 in IECs 

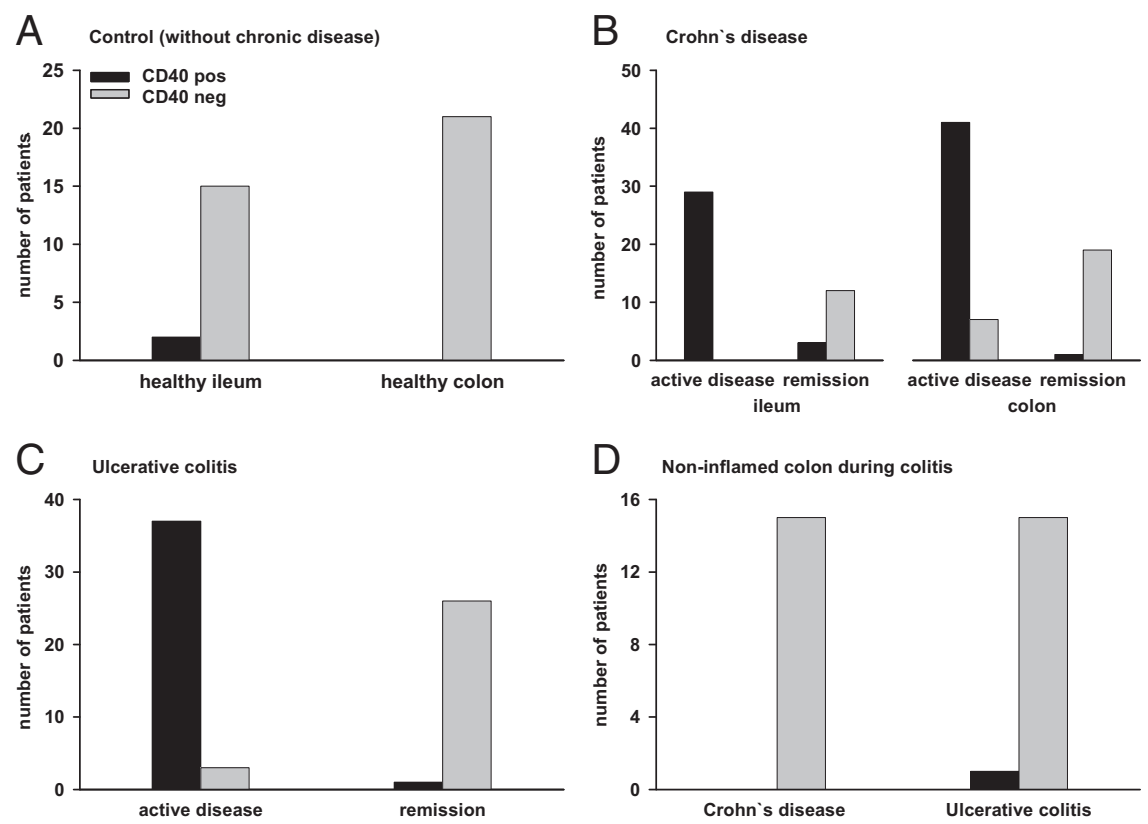

Figure 2. Quantification of the CD 40 expression in intestinal epithelial cells of IBD patients and healthy controls. The expression of CD40 in IECs was analyzed using immunofluorescence microscopy on endoscopically obtained mucosa of healthy controls and IBD patients. The immunofluorescence staining was determined and quantified as described in the Materials and Methods. CD40 was hardly ever detectable within IECs of the healthy ileum and entirely absent from the colonic epithelium of healthy controls (A). In the majority of patients with active CD ileitis (100\%) and colitis (85\%), CD 40 was consistently found in IECs as opposed to the corresponding patients in remission (ileum 20\% colon $5 \%$; B). Similar results were obtained in UC patients (active disease 92.5\%; remission $3.70 \%$; C). In contrast to the inflamed tissue in $\mathrm{CD}$ and $\mathrm{UC}$ the noninvolved adjacent mucosa almost entirely lacked the epithelial expression of CD40 (D)
(Figure 3). In HT29 (Figure 3, A and B) and SW480 cells (Figure 3, C and D), the simultaneous incubation with TNF- $\alpha$ caused an increase of the IFN- $\gamma$-induced CD40 expression. Of note, the experiments performed in T84 cells showed no additive effect TNF- $\alpha$ (Figure 3, E and F).

Quantitative RT-PCR analysis was performed to study the kinetics of the CD40 stimulation in IECs on the mRNA level. To examine the kinetics of CD40 induction IFN- $\gamma$ was applied as potent inductor in our flow cytometry experiments. In accordance with the cell surface expression unstimulated HT29 and SW480 cells lacked detection of CD40 mRNA (Figure 4, A-D). In T84 cells CD40 mRNA could be detected to some extent even without IFN- $\gamma$ influence, indicating a low constitutive expression on the mRNA level (Figure 4, E and F). On IFN- $\gamma$ stimulation, we found a strong up-regulation of the mRNA levels for CD40 in all cell lines after 12 hours (Figure 4, A, $\mathrm{C}$, and E). In HT29 and SW480 cells the expression levels gradually increased up to 72 hours (Figure 4, A and C). T84 cells showed the highest expression after a period of 24 hours (Figure 4E). Based on these data, further PCR experiments were performed to ascertain the inductive effects of IFN- $\gamma$ and TNF- $\alpha$ observed in the flow cytometry analysis. The appropriate period for each cell line was adopted for the subsequent experiments. Similar to our observation on the protein level, TNF- $\alpha$ alone was not sufficient to activate the transcription of CD40 mRNA in HT29 cells (Figure 4B). However TNF- $\alpha$ solely given to SW480 and T84 cells moderately induced the CD40 mRNA expression in a dose-dependent manner (Figure 4, D and F). Again, the combination of IFN- $\gamma$ and TNF- $\alpha$ was the most effective stimulus for CD40 in all cell lines. In HT29 and SW480 cells the additive incubation with TNF- $\alpha$ dose-dependently augmented CD40 mRNA beyond the level of IFN- $\gamma$ exposed alone (Figure 4, B and D). In T84 cells $100 \mathrm{ng} / \mathrm{ml}$ TNF- $\alpha$ was observed to be no more effective than $10 \mathrm{ng} / \mathrm{ml}$ when given in addition to the stable concentration of IFN- $\gamma$ (Figure 4F).
Particularly in HT29 cells, the up-regulation of CD40 mRNA on IFN- $\gamma$ showed a delayed kinetic. Uncommon to changes in gene expression that follow receptor ligation and downstream signaling mRNA levels for CD40 peaked not until 72 hours. This delayed response to IFN- $\gamma$ might have been attributable to an intermediate signal secreted on IFN- $\gamma$ stimulation, which in turn mediated the signaling of CD40 gene expression. To evaluate this hypothesis, HT29 cells were pulsed with IFN- $\gamma$ for 24 hours, and the supernatants were obtained and transferred onto IFN- $\gamma$-naïve HT29 cells. The transferred supernatants did not cause any increase of CD40 mRNA after 4 and 24 hours of incubation, whereas again a strong stimulation was found after 72 hours IFN- $\gamma$ used as control (Figure 5A).

sCD40L-mediated activation of CD40 was shown to contribute to the up-regulation of CD40 itself. ${ }^{27}$ With respect to the elevated SCD40L levels in IBD, this pathway might also be involved in the stimulation of epithelial CD40 in active IBD. Therefore HT29 cells, demonstrated to reliably up-regulate CD40 on IFN- $\gamma$, were treated for 72 hours with IFN- $\gamma$ to evoke the CD40 expression. Subsequently supernatants were removed and medium with or without SCD40L given for another 4, 24, and 72 hours. Time-independent the addition of SCD4OL did not exert any stimulatory effect beyond the IFN- $\gamma$-related induction of CD40 (Figure 5B).

\section{Bacterial Stimuli Do Not Influence the Expression of CD40 in Intestinal Epithelial Cells}

Similar to IFN- $\gamma$ and TNF- $\alpha$, LPS had been demonstrated to up-regulate CD40 in different cell types and is thought to be involved in the proinflammatory cascades in IBD. In flow cytometry experiments LPS used in different concentrations (10-1000 $\mathrm{ng} / \mathrm{ml})$ failed to activate the CD40 expression in HT29, SW480, and T84 cells (Figure 6). The 
A

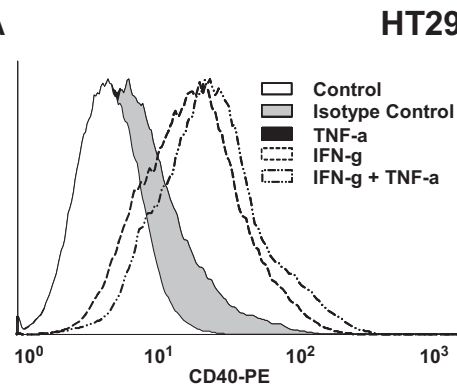

C

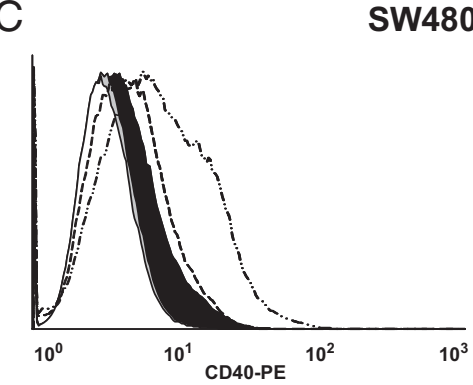

E

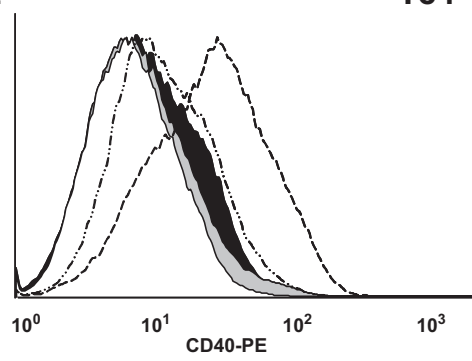

B

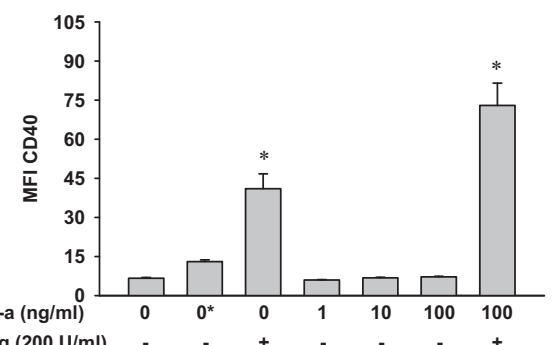

SW480

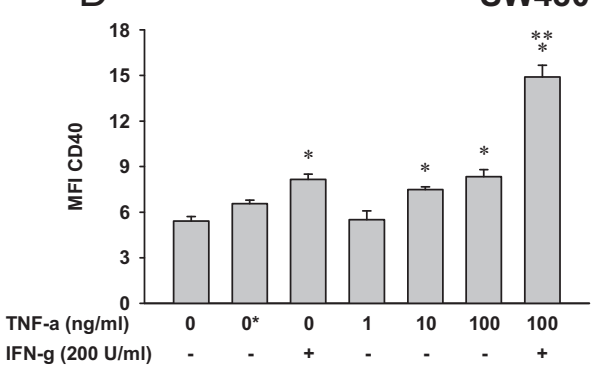

F

T84

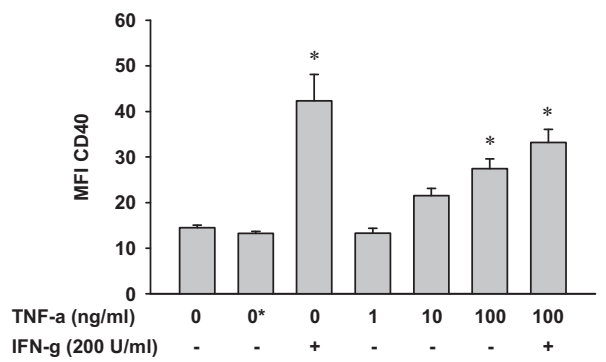

Figure 3. Influence of IFN- $\gamma$ and TNF- $\alpha$ on the surface-expression of CD40 in intestinal epithelial cells. Responsiveness of HT29 (A and B), SW480 (C and D), and T84 (E and $\mathbf{F})$ cells to 72 hours IFN- $\gamma(200 \mathrm{U} / \mathrm{ml})$ and/or TNF- $\alpha$ (1-100 $\mathrm{ng} / \mathrm{ml}$ ) were examined by flow cytometry. Histograms show one representative experiment of each cell line applying $200 \mathrm{U} / \mathrm{ml}$ IFN- $\gamma$ and 100 $\mathrm{ng} / \mathrm{ml}$ TNF- $\alpha(\mathbf{A}, \mathbf{C}$, and $\mathbf{E})$. Diagrams integrate three independent experiments, and results are displayed as mean \pm SEM $(\mathbf{B}, \mathbf{D}$, and $\mathbf{F}) ;$ Asterisks indicate isotype controls. Compared with cells without any treatment, IFN- $\gamma$ was highly effective in stimulating CD 40, particularly in HT29 and T84 cells (A-F). A dose-dependent moderate response to TNF- $\alpha$ was observed in SW480 and T84 cells (C-E), whereas HT29 cells were unresponsive to this cytokine given alone (A and B). IFN- $\gamma$ and TNF- $\alpha$ exerted synergistic effects in HT29 and SW480 cells (A-D), which was not seen in T84 cells $(\mathbf{E}$ and $\mathbf{F}) .{ }^{*} P \leq 0.05$ compared to untreated cells. ${ }^{* * *} P \leq 0.05 \mathrm{com}-$ pared with IFN- $\gamma$-treated cells. proinflammatory effect of IFN- $\gamma$ was reported to affect the susceptibility of IECs to mediators such as LPS. ${ }^{28,29}$ However, similar to its exclusive use, LPS given add on to IFN- $\gamma$ was found to exert only marginal, statistically not significant, effects. No additional stimuli, compared with IFN- $\gamma$ used alone, were detected in HT29 cells (Figure 6, A and B). In SW480 (Figure 6, C and D) and T84 cells (Figure 6, E and F) the addition of LPS to IFN- $\gamma$ resulted in a trend toward a slight increase of CD40 expression. In contrast to, eg, dendritic cells, our flow cytometry data indicated nearly unresponsiveness of the cell lines used toward LPS. We intended to confirm the results on the mRNA level and elucidate, if the unresponsiveness might be restricted to LPS or contrary comprise a broader spectrum of bacterial stimuli. Therefore experiments using HT29 cells and additionally whole E. coli were performed. Again LPS applied in concentrations up to 1000 $\mathrm{ng} / \mathrm{ml}$ was found ineffective to induce the CD40 expression after 4 and 48 hours (Figure 7A). Lack of CD40 induction was also observed after exposure to $E$. coli at these periods (Figure 7A). To prevent cell death caused by an overwhelming bacterial growth during 48 hours, gentamicin was added to the medium after an initial replication phase of 4 hours. Lack of toxicity was proven by trypan blue analysis, which showed no changes in the cell viability compared with HT29 cells solely exposed to normal medium (viability of $>95 \%$, not shown). Gentamicin alone did not influence the mRNA expression of CD40 (not shown). In the same experiments the 48 hours IFN- $\gamma$ pulse, used as control, strongly increased CD40 mRNA levels (Figure 7A). To rule out a global unresponsiveness of HT29 cells toward the bacterial stimuli applied in our study, analysis of IL-8 mRNA expression was done. Of note both stimuli, LPS and E. coli, caused a marked increase of the IL-8 mRNA levels in these cells (Figure 7B).

\section{The Engagement of CD40 on Intestinal Epithelial Cells Mediates the Secretion of IL-8}

To yield insight into a hypothesized functional relevance of the epithelial CD40 expression in IBD, we studied the secretion of IL-8 by HT29 cells in response to CD4OL binding. The secretion of IL-8 was chosen as read out for 2 reasons. First, IL-8 is well known as crucial part of the innate immune response of IECS in IBD. ${ }^{30}$ Second, the release of $\mathrm{IL}-8$ had been demonstrated in different cell types on activation via CD40. ${ }^{13,14}$ Thus IL-8 ideally links the pathophysiology of IBD, the function of the CD40/ CD40L system and the role of IECs. 
A

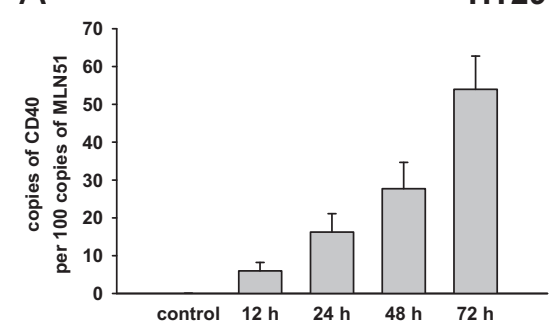

C

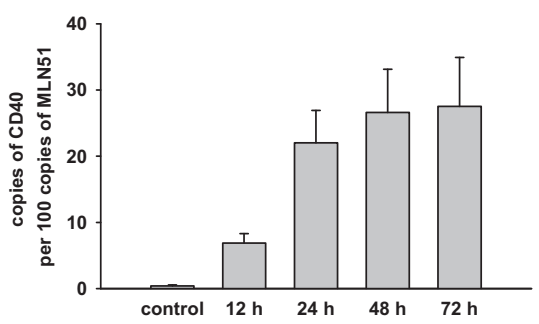

E

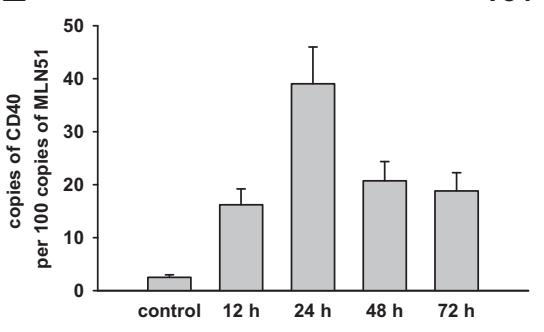

B

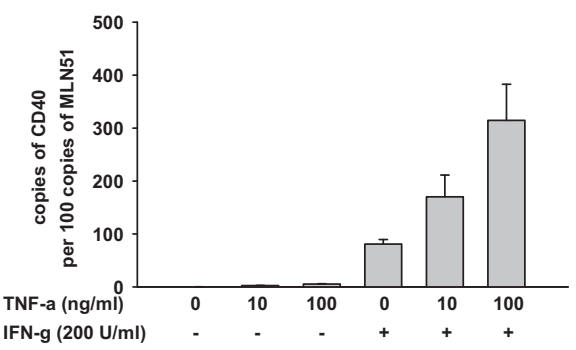

SW480

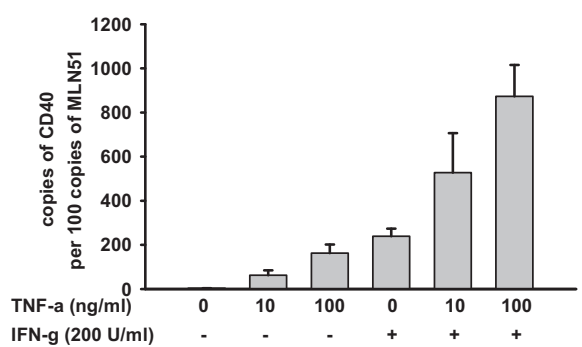

$\mathrm{F}$

T84

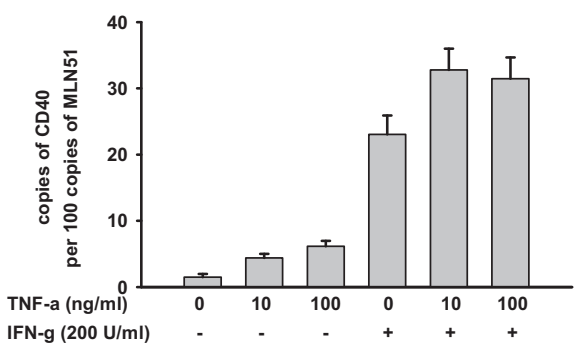

Figure 4. CD $40 \mathrm{mRNA}$ expression in intestinal epithelial cells after treatment with IFN- $\gamma$ and TNF- $\alpha$. Expression levels of CD 40 mRNA were assessed in HT29, SW480, and T84 cells using RT-PCR. Results represent the relative gene expression of CD40 and are shown as copies per 100 copies of the metastatic lymph node gene (MLN) 51. Diagrams display means of three independent experiments performed in duplicate. Error bars indicate \pm SEM. $200 \mathrm{U} / \mathrm{ml} \mathrm{IFN-} \gamma$ caused a marked increase of the CD 40 mRNA levels in all cell lines (A-E). In HT29 (A) and SW480 cells (C) highest levels were observed after treatment periods of 72 hours. In T84 cells highest levels were achieved after 24 hours (E). The appropriate periods were adopted for IFN- $\gamma$ and TNF- $\alpha$ exposure $(\mathbf{B}, \mathbf{D}$, and $\mathbf{F})$. Though less effective than IFN- $\gamma$, TNF- $\alpha$ (10 and $100 \mathrm{ng} / \mathrm{ml}$ ) dose-dependently up-regulated the CD 40 mRNA in SW480 and T84 (D and F) but not in HT29 cells (B). The combination of IFN- $\gamma$ and TNF- $\alpha$ was found to be the most effective stimulus. In HT29 and SW480 highest expression levels were seen after treatment with $200 \mathrm{U} / \mathrm{ml}$ IFN- $\gamma$ and $100 \mathrm{ng} / \mathrm{ml} \mathrm{TNF}-\alpha$ (B and $\mathbf{D})$, whereas in T84 cells the additive influence of $10 \mathrm{ng} / \mathrm{ml} \mathrm{TNF}-\alpha$ was most effective (F).
Immunofluorescence staining for IL-8 was done on tissue sections of the ileal and colonic biopsies to confirm the suspected simultaneous expression of IL-8 and CD40 during active IBD. In accordance with our CD40 data, IECs of the healthy ileum (Figure $8 \mathrm{~A}$ ) and colon (Figure 8B) lacked staining for IL-8. By contrast the epithelium of patients with active ileal (Figure $8 \mathrm{C}$ ) and colonic CD (Figure 8D) as well as active UC (Figure 8E) was found IL-8-positive, which indicated a co-expression within IECs in vivo.
To mimic the in vivo situation of CD40 activation in IBD the ligation was analyzed using cell-bound and soluble CD40L. HT29 cells pretreated with IFN- $\gamma$ for 72 hours and subsequently cocultured with nontransfected murine Lcells were used as control to demonstrate IL-8 secretion exerted by IFN- $\gamma$. The pretreatment with IFN- $\gamma$ devoid of additional stimuli by L-CD40L cells resulted in a linear increase of the IL-8 concentration in the basolateral compartment (Figure 9A). Remarkably the coculture of IFN$\gamma$-activated HT29 cells with L-CD4OL cells carrying the
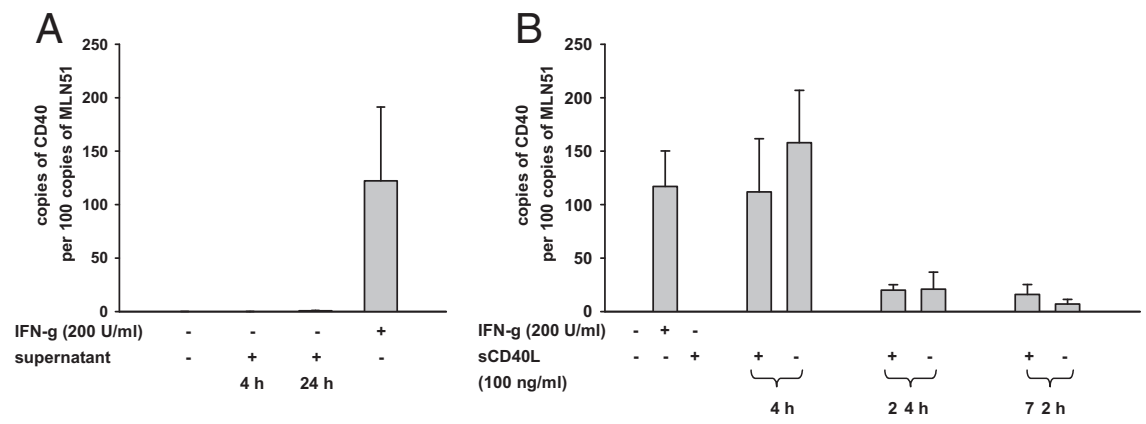

Figure 5. Effects of IFN- $\gamma$ and SCD $40 \mathrm{~L}$ on the CD40 induction in intestinal epithelial cells. Expression levels of CD 40 mRNA were determined in HT29 cells and results presented as relation to the metastatic lymph node gene (MLN) 51 mRNA expression. Data are shown as means of three independent experiments performed in duplicate and error bars indicate \pm SEM. A: Cells were pulsed with $200 \mathrm{U} / \mathrm{ml} \mathrm{IFN-} \gamma$ for 24 hours, and the supernatants were obtained and transferred to naïve cells. In these cells CD 40 mRNA expression levels were assessed 4 and 24 hours after transfer without detection of any induction. Cells exposed 72 hours to $200 \mathrm{U} / \mathrm{ml}$ IFN- $\gamma$ served as control and displayed a marked up-regulation. B: In contrast to IFN- $\gamma$, sCD $40 \mathrm{~L}(100 \mathrm{ng} / \mathrm{ml})$ given for 72 hours did not stimulate CD 40 mRNA in naïve cells. Furthermore sCD40L $(100 \mathrm{ng} / \mathrm{ml}$ given 4, 24, and 72 hours) was ineffective to further increase the CD40 expression subsequent to a IFN- $\gamma$ pulse for 72 hours. 
A

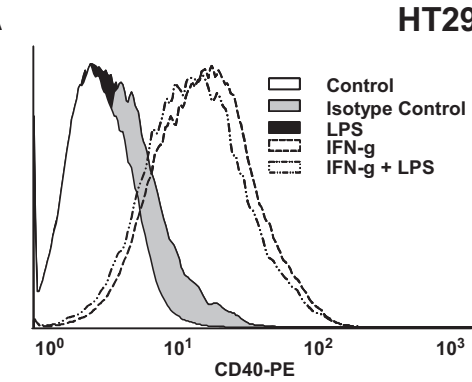

C

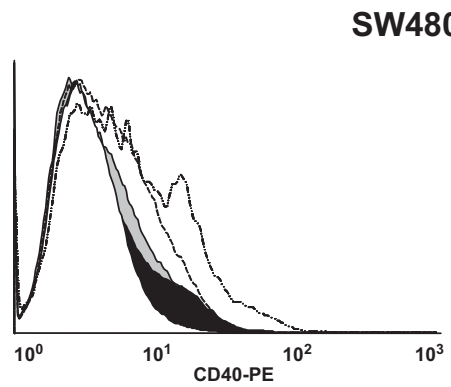

E

T84

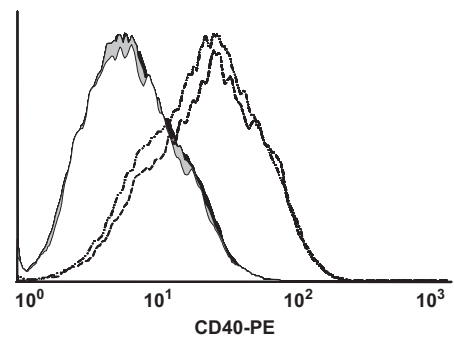

B
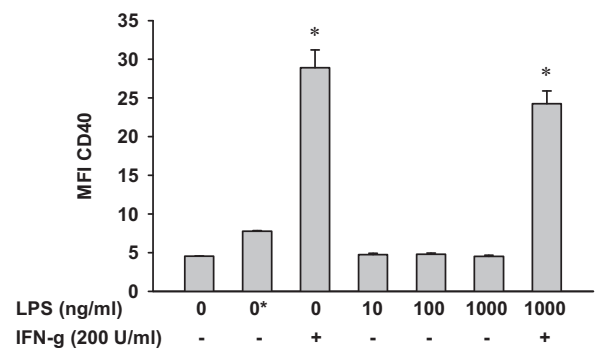

$\mathrm{D}$

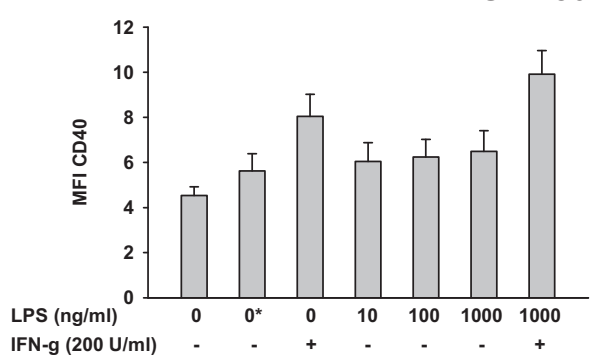

$\mathrm{F}$

T84

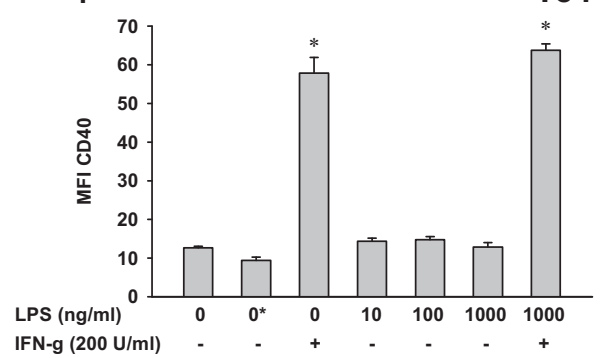

Figure 6. Effect of IFN- $\gamma$ and LPS on the surface expression of CD40 in intestinal epithelial cells. The influence of IFN- $\gamma$ and LPS on the expression of CD40 was assessed in HT29 (A and B), SW480 (C and D), and T84 cells (E and F) using flow cytometry. Cells were exposed to IFN- $\gamma$ (200 U/ml), LPS (10-1000 ng/ml), or the combination of both stimuli for 72 hours. Histograms display one representative experiment using 200 $\mathrm{U} / \mathrm{ml} \mathrm{IFN-} \gamma$ and $1000 \mathrm{ng} / \mathrm{ml}$ LPS (A, C, and $\mathbf{E}$ ). Diagrams depict the results of three independent experiments shown as mean $\pm \operatorname{SEM}(\mathbf{B}, \mathbf{D}$, and F). Asterisks indicate isotype controls. In all cell lines CD 40 was not detectable without stimulus but strongly induced by IFN- $\gamma(\mathbf{A}-\mathbf{E})$. LPS given alone did not exert inductive effects. Some synergistical effects were observed in SW480 cells when LPS was exposed in parallel with IFN- $\gamma(\mathbf{C}$ and $\mathbf{D}) .{ }^{*} P \leq 0.05$ difference compared with untreated cells. human CD40L strongly augments the secretion of IL-8 (Figure 9A). The highest concentrations of L-CD40L-triggered IL-8 were found after pretreatment with $200 \mathrm{U} / \mathrm{ml}$ IFN- $\gamma$. The strongest additive effect of L-CD40L cells was seen in HT29 cells incubated with $50 \mathrm{U} / \mathrm{ml} \mathrm{IFN-} \gamma$. In these cells, the secretion of IL-8, already activated by IFN- $\gamma$, was further up-regulated to an extent of $170 \%$ (mean).

To evaluate the efficacy of sCD40L, HT29 cells were either left unstimulated or basolaterally exposed to 200 $\mathrm{U} / \mathrm{ml}$ IFN- $\gamma$ with or without a subsequent treatment using various concentrations of SCD40L (Figure 9B). Analysis of nonstimulated cells revealed a constitutive secretion of IL-8 by HT29 cells. In line with the coculture experiments using L-cells, IL-8 was markedly induced by IFN- $\gamma$.
sCD40L applied in a concentration of 10 and $100 \mathrm{ng} / \mathrm{ml}$ was found to significantly enhance the IFN- $\gamma$-stimulated IL-8 secretion by HT29 cells. Compared with the exclusive treatment with IFN- $\gamma$, cells additionally incubated with $100 \mathrm{ng} / \mathrm{ml} \mathrm{sCD40L}$, showed 44\% higher concentrations (mean) of IL-8 in their basolateral compartment.

\section{Discussion}

In this study we provide evidence of CD40 expression in IECs during active CD and UC, identify IFN- $\gamma$ and TNF- $\alpha$ as pivotal modulators, and demonstrate clues for its involvement in the proinflammatory function of IECs in IBD.
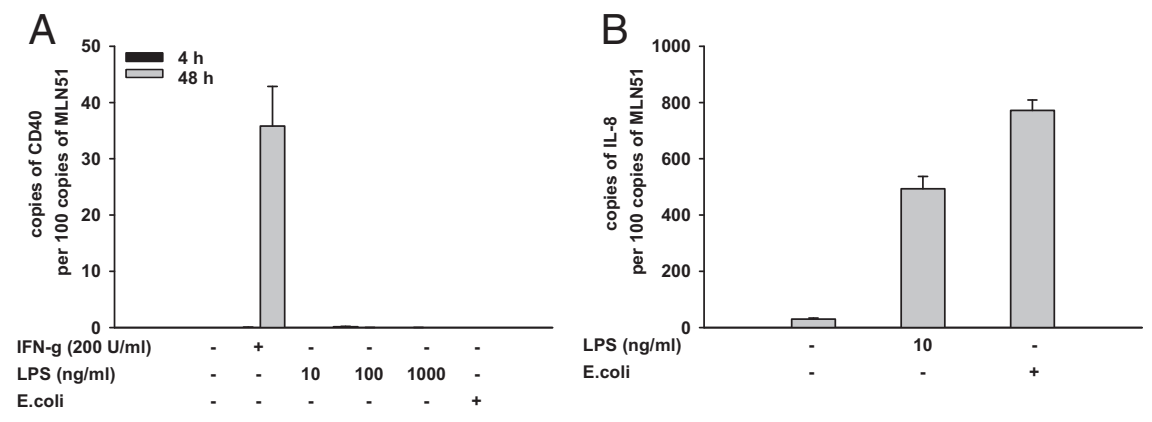

Figure 7. Bacterial effects on CD 40 and IL-8 mRNA expression in intestinal epithelial cells. Expression levels of CD40 (A) and IL-8 mRNA (B) were determined in HT29 cells and results presented as relation to the mRNA expression of the metastatic lymphnode gene (MLN) 51. Data are shown as means of three independent experiments performed in duplicate, and error bars indicate \pm SEM. A: Neither LPS (10 to 1000 $\mathrm{ng} / \mathrm{ml}$ ) nor whole $E$. coli stimulated CD $40 \mathrm{mRNA}$ expression after 4 and 48 hours. The response to $200 \mathrm{U} / \mathrm{ml}$ IFN- $\gamma$ served as control. B: In contrast to CD40 mRNA, LPS $(10 \mathrm{ng} / \mathrm{ml})$ and E. coli strongly increased the expression levels of IL-8 mRNA after 4 hours. 

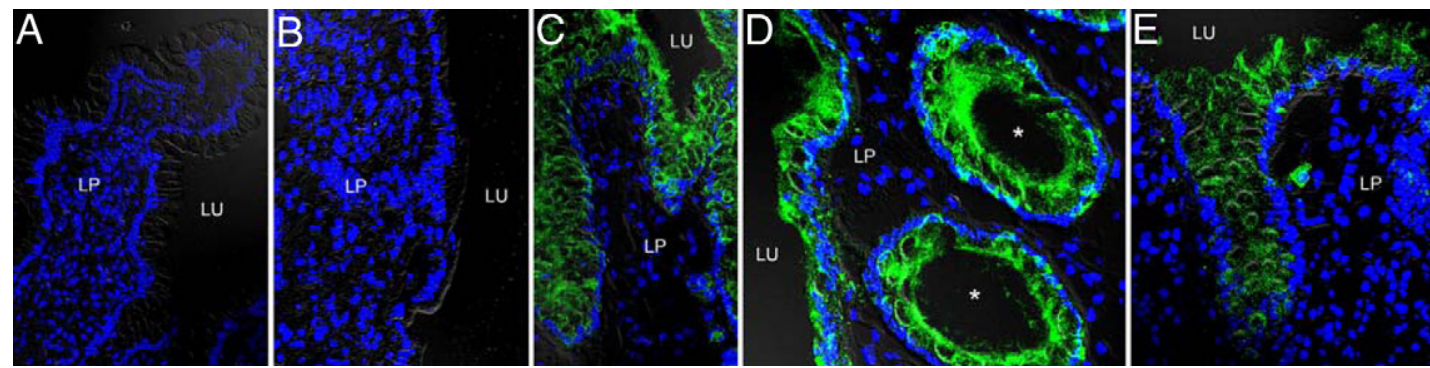

Figure 8. Mucosal expression of IL-8 in CD and UC. Immunofluorescence staining for IL-8 (green) was performed on cryosections of tissue obtained during ileocoloscopy. Sections made from the healthy ileum (A) or colon (B) lacked mucosal staining for IL-8. Tissue taken during active CD ileitis (C), CD colitis (D), and UC (E) revealed IL-8 staining in the epithelium and within cells of the lamina propria (LP). Lu indicates lumen.

Animal models of rheumatoid arthritis, experimental autoimmune encephalitis, and lupus nephritis yielded first remarks for the importance of CD40/CD40L pathways in immune diseases. ${ }^{18-20}$ Monoclonal antibodies directed against CD40L were shown to be effective in preventing disease development in these models. Antibody treatment even attenuated the established inflammation in the experimental encephalitis and nephritis and significantly improved the disease course. Consequently the CD40/ CD40L system was subject of interest in mouse models of IBD, which share common pathogenic features. Stuber et al studied the in vivo relevance of the CD40/CD40L system in the TNBS-induced colitis. ${ }^{21}$ Antibodies given against CD4OL prevented the onset of the Th-1-driven
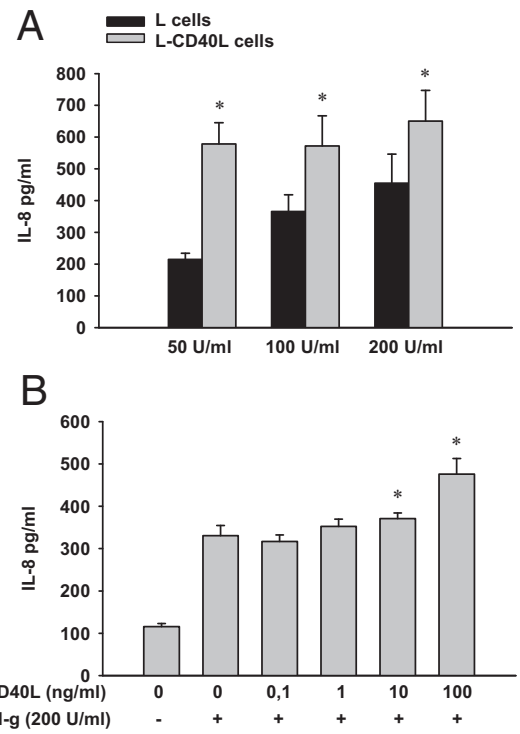

Figure 9. IL-8 secretion by intestinal epithelial cells on CD40 engagement. HT29 cells were pretreated with $200 \mathrm{U} / \mathrm{ml}$ IFN- $\gamma$ to induce the surface expression of CD40. CD40 ligation was performed for 72 hours using either murine fibroblasts (L cells) stably transfected with human CD40L (A) or human recombinant soluble CD40L (B; for details see Materials and Methods). Concentrations of IL- 8 were determined in cell-free supernatants by ELISA. IFN- $\gamma$ dose-dependently enhanced the constitutive secretion of IL-8 (A and B). Compared with nontransfected L cells, the coculture with L-CD40L cells strongly increased the IFN- $\gamma$-stimulated IL- 8 production (A). The most distinctive increase $(170 \%)$ was observed in HT29 cells treated with $50 \mathrm{U} / \mathrm{ml}$ IFN- $\gamma$, the lowest dose applied. Similar to the cell-bound activation of CD 40 , the exposure of $\mathrm{SCD} 40 \mathrm{~L}$ was also found to further augment the IFN- $\gamma$ stimulated IL- 8 secretion up to $44 \%$ (B). Results are presented as mean of three independent experiments performed in duplicate. Error bars indicate \pm SEM. ${ }^{*} P \leq 0.05$ comparing $\mathrm{L}$ versus L-CD 40L cell coculture (A) and IFN- $\gamma-$ stimulated versus additionally sCD40L-stimulated cells (B). colonic inflammation. This effect was attributed to an inhibited IL-12 production by antigen-presenting cells and the downstream lack of Th1 T cell priming. CD40L transgenic mice with high transgene copy numbers were found to develop a lethal inflammation of the gut. ${ }^{22}$ Mice showed a severe colitis resembling histopathological features of IBD. The diseased colon was marked by dense infiltrates of $\mathrm{CD}_{40 \mathrm{O}^{+}} \mathrm{CD}^{+}$and $\mathrm{CD} 8^{+} \mathrm{T}$ cells and high numbers of $\mathrm{CD}_{40} 0^{+} \mathrm{APCs}$. Thus the data available from animal models clearly point to the CD40/CD40L pathway to critically drive the inflammatory cascade in IBD and to represent a target of treatment strategies.

However the nature of its contribution to intestinal inflammation is still incompletely defined. Mice deficient for CD40 or CD40L were reported to be protected from DSS-colitis. ${ }^{31,32} \mathrm{CD} 40^{+}$endothelial cells and intestinal fibroblasts were considered to be the relevant target cells responsible for the protection. The knockout mice showed a profound reduction in the recruitment of $\mathrm{CD} 4 \mathrm{~L}^{+}$leukocytes and platelets and a significantly impaired inflammation-mediated angiogenesis. Studies in human focused on the mucosal CD40 expression in IBD and characterization of $\mathrm{CD}_{4} \mathrm{O}^{+}$cells. ${ }^{14,23,24}$ All studies demonstrated significantly higher numbers of $\mathrm{CD}_{40}{ }^{+}$cells in the inflamed ileal or colonic mucosa of IBD patients compared with healthy controls. No differences were seen regarding active CD or UC. Using immunohistochemistry, the $\mathrm{CD} 40^{+}$cells were identified as $B$ cells and to some extent endothelial cells, macrophages, and fibroblasts. Surprisingly, the epithelium was either disregarded or lacked staining for the anti-CD40 antibodies applied. These results are in striking contrast to our observations, which might rely on different technical approaches or the antibodies used. Although our data confirmed the previously observed lack of CD40 in IECs of healthy mucosa, we identified a consistent epithelial expression of CD40 within the inflamed ileal or colonic tissue of $C D$ and $U C$ patients. Similar to the previous data on lamina propria cells, CD40 in IECs was equally up-regulated during active $C D$ and UC. Several arguments support the validity of our findings. CD40 expression was confirmed in distinct intestinal epithelial cell lines on inflammatory stimuli using flow cytometry analysis. These data were almost identically reproduced on the mRNA level by RT-PCR. Furthermore, the increase of IL-8 secretion by IFN- $\gamma$-conditioned HT29 cells in response to CD40L exposure strengthens the evidence for 
the presence of CD40 in IECs during inflammation in IBD. In this regard IECs behave like epithelial cells of other organs such as tubular epithelial cells of the kidney or the airway epithelium. ${ }^{33,34}$

Our data obtained from ileal and colonic biopsies strongly suggested that the expression of CD40 in IECs is closely related to the underlying mucosal inflammation. In contrast to the inflamed mucosa in $\mathrm{CD}$ and $\mathrm{UC}$, formerly affected tissue taken during remission almost entirely lacked CD40 staining in IECs. This was in line with colonic samples obtained from noninflamed areas in the course of acute colitis in both forms of IBD. As the IBDspecific medication was found not to be correlated with the epithelial CD40 expression we suggest that not the specific medication itself but rather the actual inflammatory status of the mucosa is the critical determinant. Thus the CD40 expression in IECs is most likely not a primary defect in IBD patients that predisposes to disease development. Similar to the epithelial up-regulation of MHC II or CD86 during active IBD it rather seems to be a secondary response of IECs to an already initiated inflammation, which contributes to the perpetuation of the inflammatory processes. ${ }^{3}$

According to our immunohistochemistry results, the induction of CD40 in IECs appeared to be driven by mediators involved in the pathogenesis of $C D$ and $U C$. IFN- $\gamma$ and TNF- $\alpha$ are known to be critically implicated in the pathophysiology of both disease entities. ${ }^{1,2}$ Both cytokines had additionally been identified to stimulate CD40 in different cell types via engagement of NF- $\kappa \mathrm{B}^{12-14}$ Furthermore IFN- $\gamma$ and TNF- $\alpha$ had been demonstrated to influence IECs in various terms, among these the upregulation of $\mathrm{MHC}$ molecules and cytokine/chemokine secretion. ${ }^{3,10,11}$ In all of the different intestinal epithelial cell lines applied in our experiments IFN- $\gamma$ was found to evoke the strongest signal for CD40 induction. These results indicate that in agreement with the CD40 expression in professional APCs, mesenchymal, and other epithelial or endothelial cell types, IFN- $\gamma$ plays the central role of its modulation in IECs. ${ }^{12-14}$ The comparatively delayed response of CD40 mRNA expression after IFN- $\gamma$ stimulus in HT29 and SW480 cells might have been related to an intermediate factor secreted by these cells on IFN- $\gamma$. Consequently IFN- $\gamma$ would not have been the direct stimulus assumed. However, the results of our transfer experiments using supernatants of IFN- $\boldsymbol{\gamma}$-pulsed HT29 cells, which were found ineffective to up-regulate CD40 in naïve cells, argue against a secreted intermediate and support a delayed, but direct effect of IFN- $\gamma$. Although our results showed efficacy of TNF- $\alpha$ in the stimulation of CD40 in SW480 and T84 cells, its inductive potency was rather small compared with IFN- $\gamma$. The lack of TNF- $\alpha$ efficacy in HT29 cells might be explained by differences in the expression patterns of the TNF receptors I/II. ${ }^{35}$ IFN- $\gamma$ was reported to up-regulate the TNF- $\alpha$ receptors I and II in IECs. ${ }^{29}$ Therefore, the synergistic effect of both proinflammatory cytokines particularly in SW480 cells could be related to an IFN- $\gamma$-mediated increase in TNF receptors. Our data suggest that the concert of IFN- $\gamma$ and TNF- $\alpha$ is a key element modulating the CD40 expression in IECs. In that Th1, Th17/1 (IFN- $\gamma$ release), and Th17 cells and professional APCs (TNF- $\alpha$ release) activated during the initial phase of the disease account for this presumably secondary proinflammatory component of the epithelial immune function in IBD.

The intestinal barrier is constantly exposed to high concentrations of bacterial antigens among these LPS of E. coli. LPS signaling after TLR4 ligation was shown to induce CD40 expression via NF- $\kappa \mathrm{B}$ in macrophages and microglia. ${ }^{36}$ Thus LPS would have been a suitable candidate for the CD40 modulation in IECs. However, the data available dealing with LPS signaling in IECs are inconsistent. Whereas some authors report a constitutional functional expression of TLR4 in IECs, Abreu et al demonstrated an unresponsiveness of HT29 and T84 cells to purified, protein-free LPS attributable to the lack of MD-2 and the weak expression of TLR4. ${ }^{37,38}$ This would be in line with our observation using LPS alone to stimulate CD40. In studies performed by Suzuki et al IFN- $\gamma$ was found to augment the responsiveness to LPS, particularly in SW480 cells. ${ }^{28}$ Indeed in our experiments SW480 cells showed a slight though statistically not significant enhancement of the CD40 expression in response to LPS when given in combination with IFN- $\gamma$. Beside the conflicting data concerning LPS, human IECs, among these HT29, were reported to respond to whole commensal E. coli or purified flagellin. ${ }^{39,40}$ The response to these luminally given stimuli was mediated via apically expressed TLR-5 and downstream signaling that involves NF- $\kappa \mathrm{B}$. Thus it seemed suitable to investigate the effects of a TLR-5 agonist as regulator of the CD40 expression in HT29 cells. However, whole nonpathogenic E. coli did not exert any inductive effects on the CD40 mRNA expression in HT29 cells. The strong increase in IL-8 mRNA expression found on exposure to LPS and E. coli strongly argues against a general unresponsiveness of HT29 cells toward these bacterial stimuli and against methodical/technical reasons for the lack of CD40 induction. Our results do not point to a critical role of commensal bacteria or bacterial products in the regulation of epithelial CD40 during IBD keeping in mind that intestinal epithelial cell lines not necessarily reflect the behavior of IECs in vivo.

$\mathrm{IL}-8$ is an ideal candidate to provide evidence for a functional role of CD40 expression in IECs during active IBD. The chemokine IL-8 importantly contributes to the pathogenesis of IBD by promoting chemotaxis of neutrophiles and their pleiotropic activation. ${ }^{1,2,41}$ Izutane et al found that levels of IL-8 mRNA strictly correlated with the activity of $C D$ and UC. ${ }^{42}$ Expression levels in affected tissue were much higher as opposed to noninvolved adjacent mucosa, which is similar to our findings regarding the epithelial CD40 expression. A similar correlation was observed for the IL-8 production in IECs, which is in line with our immunofluorescence results depicting epithelial IL-8 staining in active CD and UC in contrast to noninflamed tissue. ${ }^{43}$ In renal tubular epithelial cells and intestinal fibroblasts the engagement of CD40 was demonstrated to stimulate the secretion of IL-8. ${ }^{14,33}$ We used mouse fibroblasts stably transfected with CD4OL and sCD40L to unravel an assumed IL-8 production by HT29 cells on CD40 signaling. This setting mimics the real-life 
scenario in IBD with dense infiltrates of $\mathrm{CD}_{40 \mathrm{O}^{+}} \mathrm{CD}^{+} /$ $\mathrm{CD}^{+} \mathrm{T}$ cells in close contact to IECs and elevated concentrations of SCD40L that might target IECs as well. Both the ligation of cell-bound and soluble CD40L further up-regulated the IL-8 production by HT29 cells already stimulated by IFN- $\gamma$ to induce CD40. The synergistic effect of CD40 signaling and IFN- $\gamma$ on the secretion of IL-8 by IECs again reflects the real situation in IBD. As the activation of CD40 via SCD40L was shown to enhance its expression, $\mathrm{SCD} 40 \mathrm{~L}$ is capable of potentiating its effects by amplifying its receptor. This process might have been also implicated in the CD40/CD40L interaction on IECs in IBD. However, we found no stimulating effect of SCD40L either in untreated or IFN- $\gamma$-conditioned HT29 cells. Thus our experiments do not support a contribution of SCD40L to the epithelial expression of CD40 in active IBD. Although the pathophysiological significance of CD40-mediated IL-8 secretion might be rather small compared with other well known inductors such as TNF- $\alpha$, the demonstrated effect proves the involvement of CD40 signaling in processes responsible for the inflammatory capacity of IECs.

Beside the cytokine/chemokine production the cellular activation via CD40 is known to stimulate numerous different pathways, among these the up-regulation of $\mathrm{MHC}$ antigens and costimulatory molecules such as B7 proteins. ${ }^{12,13}$ In addition, the interaction of CD40/CD4OL is suggested to be directly involved in the activation of $\mathrm{CD} 4^{+}$and $\mathrm{CD} 8^{+}$effector T cells. In active IBD, IECs were shown to stimulate $\mathrm{CD}^{+}$and $\mathrm{CD}^{+}{ }^{+}$effector $\mathrm{T}$ cells. ${ }^{5,6}$ Therefore, CD40 might be involved in various proinflammatory functions of IECs in innate and adaptive immune responses. Further studies will have to address this issue. In conclusion our study yields first insight into the expression and function of CD40 in IECs in the pathophysiology of IBD. Our data indicate that CD40 might contribute to inflammatory actions of the gut epithelium in the pathogenesis of $\mathrm{CD}$ and $\mathrm{UC}$.

\section{Acknowledgments}

We thank Heidi Schlichting and Harry Manfeldt for excellent technical assistance.

\section{References}

1. Bouma $G$ and Strober W: The immmunological and genetic basis of inflammatory bowel disease. Nat Rev Immunol 2003, 3:521-533

2. Strober W, Fuss I, Mannon P: The fundamental basis of inflammatory bowel disease. J Clin Invest 2007, 117:514-521

3. Hershberg RM and Mayer LF: Antigen processing and presentation by intestinal epithelial cells-polarity and complexity. Immunol Today 2000, 21:123-128

4. Snoeck V, Goddeeris B, Cox E: The role of enterocytes in the intestinal barrier function and antigen uptake. Microbes Infect 2005, 7:997-1004

5. Dotan I, Allez M, Nakazawa A, Brimnes J, Schulder-Katz M, Mayer L: Intestinal epithelial cells from inflammatory bowel disease patients preferentially stimulate CD4+ T cells to proliferate and secrete interferon-gamma. Am J Physiol Gastrointest Liver Physiol 2007, 292: G1630-G1640

6. Bisping G, Lügering N, Lütke-Brintrup $S$, Pauels HG, Schürmann $G$, Domschke W, Kucharzik T: Patients with inflammatory bowel disease
(IBD) reveal increased induction capacity of intracellular interferongamma (IFN-gamma) in peripheral CD8+ lymphocytes co-cultured with intestinal epithelial cells. Clin Exp Immunol 2001, 123:15-22

7. Westendorf AM, Fleissner D, Groebe L, Jung S, Bruder D, Hansen W, Buer J: CD4+Foxp3+ regulatory T cell expansion induced by antigen-driven interaction with intestinal epithelial cells independent of local dendritic cells. Gut 2009, 58:211-219

8. Eckmann L, Kagnoff MF, Fierer J: Epithelial cells secrete the chemokine interleukin-8 in response to bacterial entry. Infect Immun 1993, 61:4569-4574

9. Jung HC, Eckmann L, Yang SK, Panja A, Fierer J, Mortzycka-Wroblewska $E$, Kagnoff MF: A distinct array of proinflammatory cytokines is expressed in human colon epithelial cells in response to bacterial invasion. J Clin Invest 1995, 95:55-65

10. Stadnyk AW: Cytokine production by epithelial cells. FASEB J 1994, 8:1041-1047

11. Dwinell MB, Lügering N, Eckmann L, Kagnoff MF: Regulated production of interferon-inducible T-cell chemoattractants by human intestinal epithelial cells. Gastroenterology 2001, 120:49-59

12. Banchereau J, Bazan F, Blanchard D, Briere F, Galizzi JP, van Kooten C, Liu YJ, Rousset F, Saeland S: The CD40 antigen and its ligand. Annu Rev Immunol 1994, 12:881-922

13. van Kooten C, Banchereau J: CD40-CD40 ligand. J Leukoc Biol 2000, 67:2-17

14. Gelbmann CM, Leeb SN, Vogl D, Maendel M, Herfarth H, Schölmerich J, Falk W, Rogler G: Inducible CD40 expression mediates NFkappaB activation and cytokine secretion in human colonic fibroblasts. Gut 2003, 52:1448-1456

15. Fanslow WC, Srinivasan S, Paxton R, Gibson MG, Spriggs MK, Armitage RJ: Structural characteristics of CD40 ligand that determine biological function. Semin Immunol 1994, 6:267-278

16. Grewal IS and Flavell RA: The role of CD40 ligand in costimulation and T-cell activation. Immunol Rev 1996, 153:85-106

17. Roy M, Aruffo A, Ledbetter J, Linsley P, Kehry M, Noelle R: Studies on the interdependence of gp39 and B7 expression and function during antigen-specific immune responses. Eur J Immunol 1995, 25:596-603

18. Gerritse K, Laman JD, Noelle RJ, Aruffo A, Ledbetter JA, Boersma WJ, Claassen E: CD40-CD40 ligand interactions in experimental allergic encephalomyelitis and multiple sclerosis. Proc Natl Acad Sci USA 1996, 93:2499-2504

19. Kalled SL, Cutler AH, Datta SK, Thomas DW: Anti-CD40 ligand antibody treatment of SNF1 mice with established nephritis: preservation of kidney function. J Immunol 1998, 160:2158-2165

20. Durie FH, Fava RA, Foy TM, Aruffo A, Ledbetter JA, Noelle RJ: Prevention of collagen-induced arthritis with an antibody to gp39, the ligand for CD40. Science 1993, 261:1328-1330

21. Stuber E, Strober W, Neurath M: Blocking the CD40L-CD40 interaction in vivo specifically prevents the priming of $T$ helper 1 cells through the inhibition of interleukin 12 secretion. J Exp Med 1996, 183:693-698

22. Clegg CH, Rulffes JT, Haugen HS, Hoggatt IH, Aruffo A, Durham SK, Farr AG, Hollenbaugh D: Thymus dysfunction and chronic inflammatory disease in gp39 transgenic mice. Int Immunol 1997, 9:1111-1122

23. Battaglia E, Biancone L, Resegotti A: Emanuelli G. Fronda GR, Camussi G: expression of CD40 and its ligand, CD40L, in intestinal lesions of Crohn's disease. Am J Gastroenterol 1999, 94:3279-3284

24. Liu Z, Colpaert S, Overbergh L, Mathieu C, Heremans H, de Boer M, Boon L, DXHaens G, Rutgeerts P, Ceuppens JL: Hyperexpression of CD40 ligand (CD154) in inflammatory bowel disease and its contribution to pathogenic cytokine production. J Immunol 1999, 163: 4049-4057

25. Danese S, Katz JA, Saibeni S, Papa A, Gasbarrini A, Vecchi M, Fiocchi C: Activated platelets are the source of elevated levels of soluble CD40 ligand in the circulation of inflammatory bowel disease patients. Gut 2003, 52:1435-1441

26. Garrone P, Neidhardt EM, Garcia E, Galibert L, van Kooten C Banchereau J: Fas ligation induces apoptosis of CD40-activated human B lymphocytes. J Exp Med 1995, 182:1265-1273

27. Chen K, Huang J, Gong W, Zhang L, Yu P, Wang JM: CD40/CD40L dyad in the inflammatory and immune responses in the central nervous system. Cell Moll Immunol 2006, 3:163-169

28. Suzuki M, Hisamatsu T, Podolsky DK: Gamma interferon augments the intracellular pathway for lipopolysaccharide (LPS) recognition in 
human intestinal epithelial cells through coordinated up-regulation of LPS uptake and expression of the intracellular Toll-like receptor 4-MD-2 complex. Infect Immun 2003, 71:3503-3511

29. Wang F, Schwarz BT, Graham WV, Wang Y, Su L, Clayburgh DR, Abraham C, Turner JR: IFN-gamma-induced TNFR2 expression is required for TNF-dependent intestinal epithelial barrier dysfunction. Gastroenterology 2006, 131:1153-1163

30. MacDermott RP, Sanderson IR, Reinecker HC: The central role of chemokines (chemotactic cytokines) in the immunopathogenesis of ulcerative colitis and Crohn's disease. Inflamm Bowel Dis 1998, 4:54-67

31. Vowinkel T, Anthoni C, Wood KC, Stokes KY, Russell J, Gray L, Bharwani S, Senninger N, Alexander JS, Krieglstein CF, Grisham MB, Granger DN: CD40-CD40 ligand mediates the recruitment of leukocytes and platelets in the inflamed murine colon. Gastroenterology 2007, 132:955-965

32. Danese S, Scaldaferri F, Sgambato A, Rutell S, Cittadini A, Pique JM, Panes J, Katz JA, Gasbarrini A, Fiocchi C: Critical role of the CD40 CD40-ligand pathway in regulating mucosal inflammation-driven angiogenesis in inflammatory bowel disease. Gut 2007, 56:1248-1256

33. van Kooten C, Woltman AM, Daha MR: Immunological function of tubular epithelial cells: the functional implications of CD40 expression. Exp Nephrol 2000, 8:203-207

34. Cagnoni F, Oddera S, Giron-Michel J, Riccio AM, Olsson S, Dellacasa P, Melioli G, Canonica GW, Azzarone B: CD40 on adult human airway epithelial cells: expression and proinflammatory effects. J Immunol 2004, 172:3205-3214

35. Holtmann MH, Neurath MF: Differential TNF-signaling in chronic inflammatory disorders. Curr Mol Med 2004, 4:439-444

36. Qin H, Wilson CA, Lee SJ, Zhao X, Benveniste EN: LPS induces CD40 gene expression through the activation of NF-kappaB and STAT1alpha in macrophages and microglia. Blood 2005, 106:3114-3122

37. Cario E: Bacterial interactions with cells of the intestinal mucosa. Gut 2005, 54:1182-1193

38. Abreu MT, Vora P, Faure E, Thomas LS, Arnold ET, Arditi M: Decreased expression of Toll-like receptor- 4 and MD-2 correlates with intestinal epithelial cell protection against dysregulated proinflammatory gene expression in response to bacterial lipopolysaccharide. J Immunol 2001, 167:1609-1616

39. Bambou JC, Giraud A, Menard S, Begue B, Rakotobe S, Heyman M, Taddei F, Cerf-Bensussan N, Gaboriau-Routhiau V: In vitro and ex vivo activation of the TLR5 signaling pathway in intestinal epithelial cells by a commensal Escherichia coli strain. J Biol Chem 2004, 279:42984-42992

40. Rochon M, Römling U: Flagellin in combination with curli fimbriae elicits an immune response in the gastrointestinal epithelial cell line HT-29. Microbes Infect 2006, 8:2027-2033

41. Mitsuyama K, Toyonaga A, Sasaki E, Watanabe K, Tateishi H, Nishiyama T, Saiki T, Ikeda H, Tsuruta O, Tanikawa K: IL-8 as an important chemoattractant for neutrophils in ulcerative colitis and Crohn's disease. Clin Exp Immunol 1994, 96:432-436

42. Izutani R, Loh EY, Reinecker HC, Ohno Y, Fusunyan RD, Lichtenstein GR, Rombeau JL, MacDermott RP: Increased expression of Interleukin-8 mRNA in ulcerative colitis and Crohn's disease mucosa and epithelial cells. Inflammatory Bowel Diseases 1995, 1:37-47

43. Mazzucchelli L, Hauser C, Zgraggen K, Wagner H, Hess M, Laissue $\mathrm{JA}$, Mueller C: Expression of interleukin-8 gene in inflammatory bowel disease is related to the histological grade of active inflammation. Am J Pathol 1994, 144:997-1007 